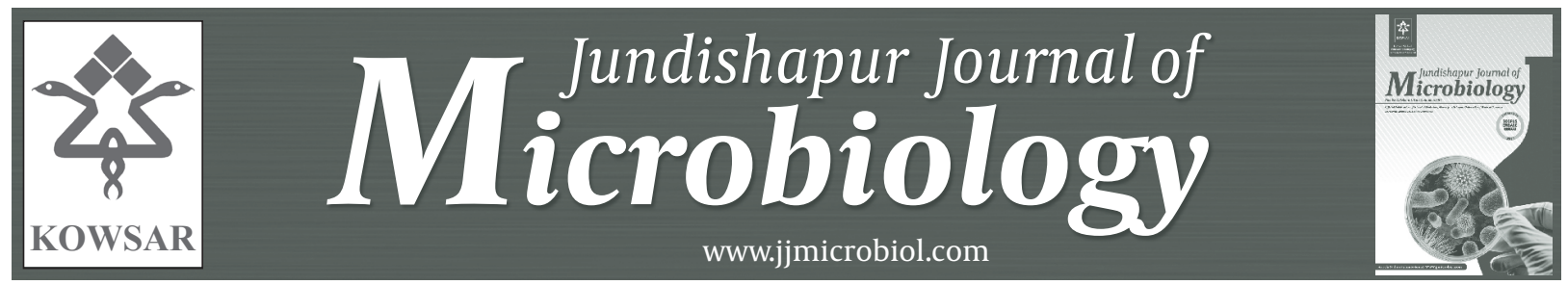

\title{
Increasing the HCV Prevalence in Ahvaz: Bells Ring!!
}

\author{
Seyyed Mohammad Miri ${ }^{1}$, Seyed Moayed Alavian ${ }^{1, *}$ \\ ${ }^{1}$ Baqiyatallah Research Center for Gastroenterology and Liver Disease, Baqiyatallah University of Medical Sciences, Tehran, Tehran, IR Iran \\ *Corresponding author Seyed Moayed Alavian, Baqiyatallah Research Center for Gastroenterology and Liver Disease, Baqiyatallah University of Medical \\ Sciences, Tehran, IR Iran. Tel/Fax: +98-21 88621755, E-mail: alavian@thc.ir.
}

Keywords: prevalence; hepatitis C virus; HBV

Article type: Letter; Received: 07 Jul 2012, Revised: 15 Aug 2012, Accepted: 25 Aug 2012; DOI: 10.5812/jjm.7130

-Please cite this paper as:

Miri SM, Alavian SM. Increasing the HCV Prevalence in Ahvaz: Bells Ring!! Jundishapur J Microbiol. 2013;6(3): 309-10. DOI: 10.5812/ jjm.7130.

Copyright (C) 2013, Ahvaz Jundishapur University of Medical Sciences; Published by Kowsar Corp.

This is an Open Access article distributed under the terms of the Creative Commons Attribution License (http://creativecommons.org/licenses/by/3.0), which permits unrestricted use, distribution, and reproduction in any medium, provided the original work is properly cited. 


\section{Dear Editor,}

We read with interest the published article by Nikbakht et al.. in your journal recently (1). The study reported the low prevalence of hepatitis B virus (HBV) infection among 712 infertile couples in Ahvaz, but higher hepatitis $C$ virus (HCV) infection than the previous reported studies from Iran (2). Although the study could determine a complete set of infertile patients, it could not be extended to the general population since it was not the desired representative of general population as well.

Defining the main risk factors for finding the routs of transmission is of utmost importance when studying the HBV and HCV infections in the communities (3). Unfortunately Risk factors are not discussed in the mentioned study may be due to matters of retrospective design of the study. Furthermore, the study could not succeed to define the relationship between age groups among positive cases. Despite the fact that lots of similar studies in the world reported the male dominance in HCV and HBV patients, the current study declared inverse relationship (female dominance: 6 females versus 5 males in HBV and 6 females versus 3 males in HCV). According to prevalence of $\mathrm{HBV}$ and $\mathrm{HCV}$ in the normal population, strangely HCV infection is reported similar to HBV infection which should be considered for readers. Alavian SM et al. already stated that HCV infection as an emerging disease in Iran should be considered carefully (4) which probably due to changing of risk factors in Ahvaz and altering the harmony of causes in the region it could be explained. Another strong point of the study is reporting the HBV infection in age groups lower than 18 years which is based on implementation of national vaccination program since 1993 for all neonates in Iran (5).

Although drug abuse has been the major routes of HCV transmission in Iran, the current study has not studied the role of this important risk factor. The importance of studying the role of history of IDUs is so high in every epidemiological studies and as the main risk factor for
HCV especially in Iran should be considered since it could lead to a higher prevalence of HCV infection in each population $(6,7)$. For instance in a previous study in Ahvaz among IDUs showed that the HCV rate is $30.9 \%$ in comparison with $\mathrm{HBV}$ which was reported in $3.6 \%$ of patients (8).

\section{Acknowledgements}

\section{Financial Disclosure}

None declared.

\section{Funding/Support}

None declared.

\section{References}

1. Nikbakht R, Saadati N, Firoozian F. Prevalence of HBsAg, HCV and HIV Antibodies Among Infertile Couples in Ahvaz, South-West Iran.JundishapurJ Microbiol. 2012;5(2):393-397

2. Mohebbi SR, Sanati A, Cheraghipour K, Rostami Nejad M, Shalmani HM, Zali MR. Hepatitis C and hepatitis B virus infection: epidemiology and risk factors in a large cohort of pregnant women in lorestan, west of iran. Hepat Mon. 2011;11(9):736-9

3. Hashmi A, Saleem K, Soomro JA. Prevalence and Factors Associated with Hepatitis C Virus Seropositivity in Female Individuals in Islamabad, Pakistan. Int J Prev Med. 2010;1(4):252-256

4. Alavian SM, Adibi P, Zali MR. Hepatitis C virus in Iran: Epidemiology of an emerging infection. Arch Iran Med. 2005;8:84-90

5. Alavian SM, Fallahian F, Bagheri-Lankarani K. The Changing Epidemiology of Viral Hepatitis B in Iran. J Gastrointestin Liver Dis. 2007;16(4):403-406

6. Ataei B, Tayeri K, Kassaian N, Farajzadegan Z, Babak A. Hepatitis B and $\mathrm{C}$ among Patients Infected with Human Immunodeficiency Virus in Isfahan, Iran: Seroprevalence and Associated Factors. Hepat Mon. 2010;10(3):188-92

7. Azarkar Z, Sharifzadeh G. Evaluation of the Prevalence of Hepatitis B, Hepatitis C, and HIV in Inmates with Drug-Related Convictions in Birjand, Iran in 2008. Hepat Mon. 2010;10(1):26-30

8. Alavi SM, Behdad F. Seroprevalence Study of Hepatitis C and Hepatitis B Virus among Hospitalized Intravenous Drug Users in Ahvaz, Iran (2002-2006). Hepat Mon. 2010;10(2):101-4 